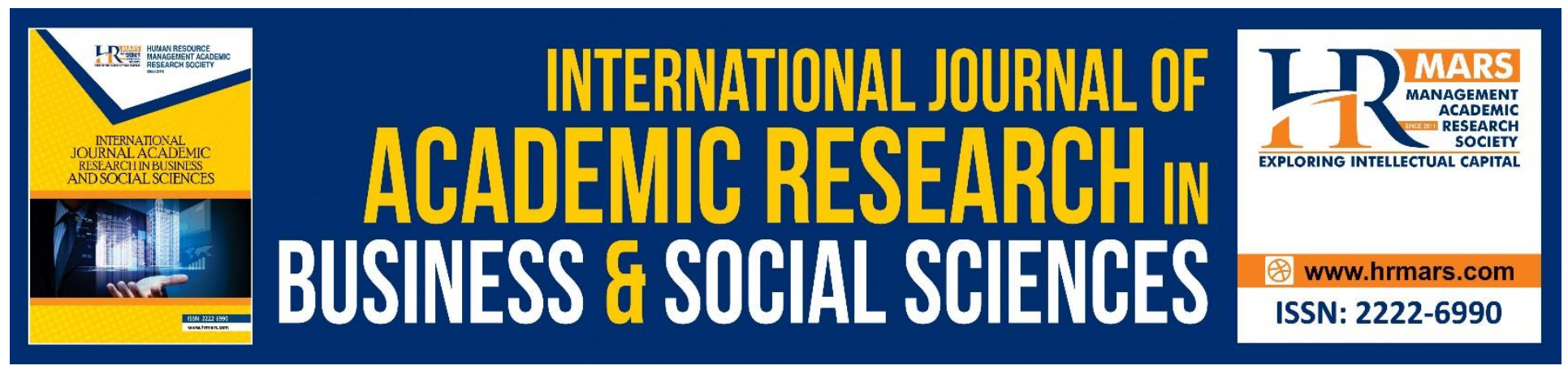

\title{
Extending the Chain of Relationships between Organizational Trust and Intention to Remain, among Self-initiated Academic Expatriate: A Conceptual Model
}

Asniza Yusuf and Subramaniam a/l Sri Ramalu

To Link this Article: http://dx.doi.org/10.6007/IJARBSS/v8-i9/4702

DOI: $10.6007 /$ IJARBSS/v8-i9/4702

Received: 17 August 2018, Revised: 27 Sept 2018, Accepted: 29 Sept 2018

Published Online: 13 October 2018

In-Text Citation: (Yusuf \& Ramalu, 2018)

To Cite this Article: Yusuf, A., \& Ramalu, S. a/l S. (2018). Extending the Chain of Relationships between Organizational Trust and Intention to Remain, among Self-initiated Academic Expatriate: A Conceptual Model. International Journal of Academic Research in Business and Social Sciences, 8(9), 1370-1380.

Copyright: (c) 2018 The Author(s)

Published by Human Resource Management Academic Research Society (www.hrmars.com)

This article is published under the Creative Commons Attribution (CC BY 4.0) license. Anyone may reproduce, distribute, translate and create derivative works of this article (for both commercial and non-commercial purposes), subject to full attribution to the original publication and authors. The full terms of this license may be seen at: $\underline{\text { http://creativecommons.org/licences/by/4.0/legalcode }}$

Vol. 8, No. 9, September 2018, Pg. 1370 - 1380

Full Terms \& Conditions of access and use can be found at http://hrmars.com/index.php/pages/detail/publication-ethics 


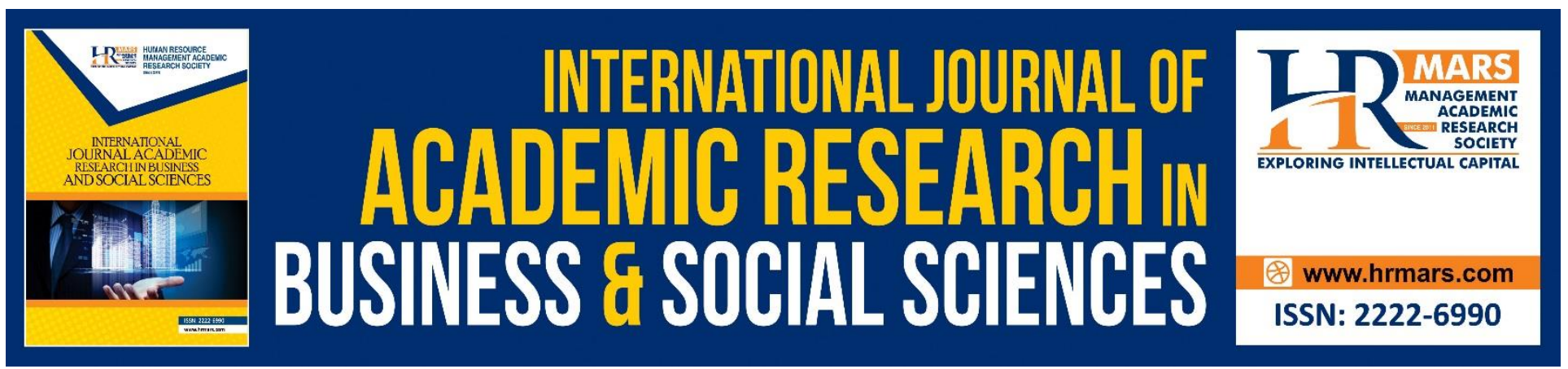

\title{
Extending the Chain of Relationships between Organizational Trust and Intention to Remain, among Self-initiated Academic Expatriate: A Conceptual Model
}

\author{
Asniza Yusuf ${ }^{1}$ and Subramaniam a/l Sri Ramalu² \\ Othman Yeop Abdullah Graduate School of Business, Universiti Utara Malaysia, 06100 UUM Sintok, \\ Kedah Malaysia \\ Email: asniza_yusuf@yahoo.com, subra@uum.edu.my
}

\begin{abstract}
Research on self-initiated expatriates infrequently pays attention to the potential gap between the trust organisations seeks to establish, and employees' intention to remain. Understanding this situation might help in gaining better perspective on how a university may attempt to boost the intention to remain capabilities for the retention of academic expatriates. A model is proposed for the purpose of identifying the critical antecedents of self-initiated academic expatriates. The model predicts that organizational trust is a predictor of intention to remain. In this paper, it is asserted that the success of the expatriation process depends not only on the self-initiated academic expatriate's competencies and skills, but also on organizational trust during the process of carrying out their assignments. The paper is proposing the Social Exchange Theory as a linkage between trust and intention to remain to explain the reciprocity as a result of exchange relationship between the higher education institutions and self-initiated academic expatriates. Upon model validation, the paper could offer practical interventions for human resource practitioners and the management to assist the recruiting universities towards managing knowledge transfer involving self-initiated academic expatriates in Malaysia.
\end{abstract}

Keywords: Organizational Trust, Intention to Remain, International Assignment, Self-Initiated Academic Expatriates, Organizational Expatriate

\section{Introduction}

Academics who seek employment beyond their national borders may face challenges beyond those experienced by academics who never "leave home" for work (Basit \& Duygulu, 2018). Yet, in an era of increasing globalisation, particularly in the higher education sector, this is a phenomenon 
INTERNATIONAL JOURNAL OF ACADEMIC RESEARCH IN BUSINESS AND SOCIAL SCIENCES Vol. 8, No. 9, Sept. 2018, E-ISSN: 2222-6990 @ 2018 HRMARS

experienced by more and more academics worldwide described in this research as self-initiated academic expatriates (Zeffane \& Melhem, 2017).

Expatriates are known as individuals who reside in another country in order to perform an international task or assignment (Srivastava \& Panday, 2012; Doherty, Richardson \& Thorn, 2013) which falls into two types, organizational expatriations (OEs) assigned by multinational companies (MNC) to work abroad (Sri Ramalu, 2010); and individual-initiated movement to take up international assignments on their own, known as self-initiated expatriates (SIEs) (Isakovic \& Forseth Whitman, 2013; Doherty et al., 2013). There are approximately 50.5 million of expatriates (both the OEs and SIES) around the world and the growth of the total number of expatriates is expected to reach 87.5 million by 2021 (Finaccord, 2018).

Most literatures are focusing on organizational expatriation (OEs); those who are ordered and financed by the organization they work with, to foreign post (Sri Ramalu, Che Rose, Uli \& Kumar, 2012). However, there are still inadequate studies done on self-initiated expatriation (Abdel-Rahman, Sri Ramalu \& Subramaniam, 2017). Self-initiated expatriation represents individual's mobility to move through their own agency (rather than through an organizationally-assigned expatriation) to another country for an undetermined duration (Al-Ariss \& Crowley-Henry, 2013). They are equipped with their own competence and proficiency to work in diverse industries and conditions (Al Shammari, 2013). While expatriation is studied commonly among OEs and traditional sectors such as financial services, manufacturing and service sector, the education sector has witnessed rather greater effect of globalization in terms of expatriate employment. Most Higher Education Institutions (HEIs) in the present days contemplating internationalisation as one of their long term objectives. So do the requirements by ranking institutions which include internationalisation as a criteria for ranking universities (Trembath, 2016). The internationalization of education and greater international presence among Higher Education Institutions, further fuelled the demand for self-initiated academic expatriates (Lewis \& Altbach, 1996; Altbach \& Knight, 2007).

This is to serve as a stimulus for enhancement through interaction, experience and exposure for students from local HEls into the global sphere (MOHE, 2012) as Malaysia is of no exception in this scenario and has liberalized its higher education system to be more open and internationalized in achieving Mission 2020. Our HEls aim to achieve 15 percent target for international staff recruitment by 2020, under the National Higher Education Strategic Plan (2007-2020) (MOHE 2011). To serve this competitive yet promising market, the HEls are aggressively recruiting academic expertise, worldwide; and greater numbers of academic expatriates are recruited outside their home country of origin (Lewis et al., 1996; Tietze \& Dick, 2009). The growing number of international mobility of academic expatriation will raise the issue of managing SIEs which becomes more complex and challenging. Due to significance importance of this internationalization, it is necessary for the Higher Education Institutions to retain the self-initiated academic expatriate to continuously serve in the universities (Zeffane et I., 2017). It is believed that strongly trust in organization becomes a vital important factor to motivate ones to remain longer. 
Recent development in the realm of organizational sciences reflect on the importance of trust relationships for sustaining intention to remain (Li, Kim \& Zhao, 2017). Therefore, the issues of organizational trust have become increasingly central to the study of organizations in the domain of political sciences, policy studies, law, organizational behaviour, organizational psychology and economics. Trust is important because of the strong desire to understand how to create effective cooperation within organizations (Zeffane et al., 2017). Hassan, Toylan, Semercioz \& Aksel (2012) discussed the consequences of initiating and preserving trust which resulted in shaping business to business and interpersonal relations. Employee who do not trust their management and organization are less likely to be committed and effective (Tlaiss \& Elamin, 2015).

Several studies have found high indications of intention to leave amongst self-initiated expatriates (Schoepp \& Forstenlechner, 2011; Romanowski \& Nasser, 2014). Both of these factors have been attributed to different forms of dissatisfaction among expatriates (Leung, Liang \& Chan, 2016). The organizational and human costs related to expatriate failure (in terms of both, reduced effectiveness and turnover) have been shown to be enormous (Selmer \& Lauring, 2011; Cerdin \& Selmer, 2014). In a study of the effects of expatriate's intention to remain on organizational trust, Gillespie, Dietz and Lockey (2014) demonstrated that there is a significant relationship between organizational trust and intention to remain. This is why it is critical for universities to reduce high turnover of their expatriate academic workforces.

Research has suggested that such high levels of turnover are potentially avoidable, and that universities can take steps towards mitigation, for example by taking steps that leads to increased organizational citizenship behaviour as well as increased work performance of academic expatriates.

\section{Literature Review Intention to Remain}

Intention to remain is described here as the sentiments, judgements and feelings of employees regarding their willingness to stay in their present organization (Tourangeau et al., 2014). Research carried out by previous scholars has revealed that intention to remain had the prospect to decreasing the amount of cost to be spent on the engagement of new staff. It is said that it is members of staff who display a greater level of intention to remain are the ones who are more successful and are also likely to shoot their careers within their current organization and subsequently, in contributing their overall efforts to their organizations (Harun, Asiah, Shahid, \& Othman, 2016). In a study that employed 13,000 Canadian employees, it was revealed that employees who indicate the desire to stay in their current place of work were more satisfied with their work. Research has also revealed that the lack of intention to remain negatively impacts on work confidence and working motivation of employees which can lead to absent-mindedness or leaving. Intention to remain carries the meaning of employee's commitment level and the readiness to stay hired in the organization besides the likelihood of an action to take place regarding desire to stay in the organization (Womack, Leuty, Bullock-Yowell, \& Mandracchia, 2018). It is the propensity to leave and acts as vital factor of turnover (Khoele \& Daya, 2014). Psychologically, employee will opt to remain in or quit from their employing organization (Schwepker, 2001). However, organization has to bear the cost of new recruitment if little concern is given on intention to remain rather than employee's turnover (Dalessio, Silverman \& 
INTERNATIONAL JOURNAL OF ACADEMIC RESEARCH IN BUSINESS AND SOCIAL SCIENCES

Vol. 8, No. 9, Sept. 2018, E-ISSN: 2222-6990 @ 2018 HRMARS

Shuck, 1986). Nonetheless, most organizations are putting effort to minimize turnover in a manner to retain the key competence (Govaerts, Kyndt, Dochy \& Baert, 2011). Dissatisfied individuals will hardly stay longer in the organization which eventually cause them not to remain (Jung \& Yoon, 2015).

\section{Organizational Trust}

Events in recent years has suggested that trust has transformed to become a very crucial subject among academics and in a variety of social science specializations such as management, sociology, psychology, and economics (Mayer et al., 1995; Cummings \& Bromiley, 1996; Mayer \& Davis, 1999; Schoorman, Mayer \& Davis, 2007; Colquitt, Scott \& LePine, 2007). Trust as an idea has a lot to do with individual ascriptions regarding other employee's intents and purposes which reveals their behaviour. Unambiguously, trust involves "positive expectations about others." These ascriptions are swayed by broad-spectrum opinions and expectations of individuals about the treatment they will receive from others (Mayer et al., 1995). Numerous studies in the past, revealed that trust is intensely associated with several employee attitudes, including intention to remain (Dirks \& Ferrin, 2002; Brasheara, Manolis \& Brooks, 2005; Mulki, Jaramillo \& Locander, 2008; McKnight, Phillips \& Hardgrave, 2009; DeConinck, 2011; Harhara, Singh \& Hussain, 2015). These associations have been discovered to be relevant to both private and public sectors organizations (Balkan, Serin \& Soran, 2014; Ertürk, 2014). The reasoning behind these associations is that employees experience high trust when they are more likely to feel safe and comfortable in their job which makes them less inclined to want to leave. At the same time, when distrust is shown to them, the tendency is that they would become worried and uncomfortable in their job and as a result would prefer to quit the job. Dirks et al. (2002) conducted a meta-analysis study which revealed that trust remains a key factor in determining employee intention to remain. Similarly, a study of trust was conducted on the Australian context; the findings by Ferres, Connell and Travaglione (2005) showed that workfellows trust was a significant predictor of intention to remain.

Costigan, Insinga and Berman (2012) conducted a study in four countries and the result showed that employees' trust of their supervisor was a significant predictor of intention to remain. Similarly, in a study conducted by Mulki et al. (2013) among 344 salespeople, trust was discovered to be significant to intention to remain. Several previous reports have established that there is low trust among public sector employees (Morgan \& Zeffane, 2003; Top, Akdere \& Tarcan, 2015). In a comparative study of public and private sector employees in India, it was also discovered that the trust level among employees who work in the private sector turned out to be higher than those of their counterparts in the public sector (Shahnawaz \& Goswami, 2011). The revelations from a recently conducted comparative study in Turkey also showed that the trust levels was higher among private sector employees than those of employees from the public sector (Top et al., 2015).

Nevertheless, earlier mentioned considerations do not have much influence on public sector organizations in the Malaysian context. In that context, public employees seem to be relatively more loyal and more trusting of their organization and its management (Al-Ali, 2008). For instance, in the 
INTERNATIONAL JOURNAL OF ACADEMIC RESEARCH IN BUSINESS AND SOCIAL SCIENCES

Vol. 8, No. 9, Sept. 2018, E-ISSN: 2222-6990 @ 2018 HRMARS

study of knowledge sharing in Malaysia, Sandhu, Jain and Ahmad (2011) found the level of trust to the very high among employee in the public sector.

\section{Intention to Remain and Organizational Trust}

Organizational trust is found to be associated with intention to remain (Kashyap \& Rangnekar, 2016) where the presence of trust in leaders will discourage subordinates intention to leave the organization. Most organizations are focusing on why employee tend to quit. Thirapatsakun, Kuntonbutr \& Mechinda (2014) argued that trust and organizational commitment should be increased in order to encourage intention to remain among employees. Regardless of any circumstances which might happen to a country's economy, organizations still have to remain the key competent, in achieving effectiveness (Thirapatsakun et al., 2014). In ensuring a conducive working environment, members in an organization must work together, mutually and effectively by displaying interpersonal trust as a key determinant factor for the favourable outcomes (Ozturk, Hancer \& Wang, 2014). Social Exchange Theory (Blau, 1964) put forward the idea of social exchange between persons to reciprocate over time. In this case, mutual trust between employee and the organization become significant important so that these people will be more concern and highly productive (Goodwin, Groth \& Frenkel, 2011), and ultimately remain to serve longer (Yuan, Yu, Lee \& Ning, 2014). As suggested by Robinson (1996), breach of trust will cause negative impact on employee's intention to remain in the organization. Ozturk et al. (2014) conducted a survey on hotel employees and found that interpersonal trust (affective and cognitive trust) can boost their intention to remain. Employee who feel trusted will be more committed and work harder, at the end will remain longer working at the current workplace (Mustapha, Ahmad, Uli \& Idris, 2010). Soomro, Halepoto \& Memon (2015) discovered that high level of trust will affect productivity in a way that it increases the speed of production, boost performance and ultimately lower turnover cost. Khan (2015) proclaimed that when people leave an organization, they actually try to move away from the bosses and not the organization in which they work normally resulting from poor leadership, and at the end trust can't be developed. Consequent upon this, turnover intention becomes a pertinent issue.

Drawing from this discussion, a conceptual framework was proposed, as illustrated in figure 1 . It shows that organizational trust have a positive and significant relationship with intention to remain and in turn enhances effectiveness.

\section{Conceptual Framework}

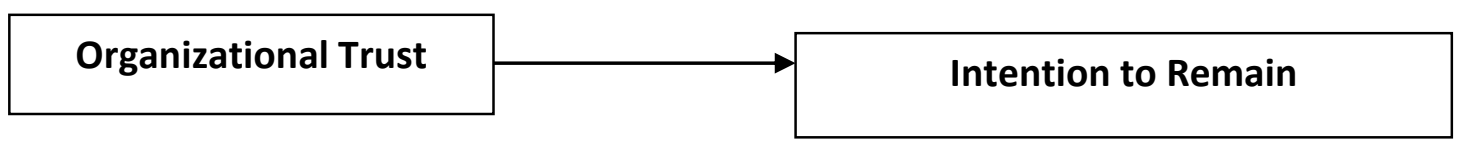

Figure 1: Conceptual Framework 
INTERNATIONAL JOURNAL OF ACADEMIC RESEARCH IN BUSINESS AND SOCIAL SCIENCES

Vol. 8, No. 9, Sept. 2018, E-ISSN: 2222-6990 @ 2018 HRMARS

\section{Proposition}

Proposition 1: Organizational trust is positively related to Intention to remain

Proposition 2: Organizational trust is negatively related to Intention to remain

\section{Methodology}

This is a conceptual paper which is carried out based on extensive review of literatures, articles, thesis and books. The total number of the self-initiated academic expatriates in Malaysia is 1595 (Ministry of Home Affairs, 2016). However, for the purpose of this intending research, only 246 self-initiated academic expatriates would be chosen as the population for this study. A probability simple random sampling method will be applied and a total of 246 questionnaires will be distributed through a representative appointed at each university campus. The distribution and collection of the survey instruments will take about four months.

\section{Conclusion}

The major contribution of this research is that it is contextualised on the Malaysian setting which also reflects the nobility of the study. The study add to embryonic and developing body of knowledge by refining the scope of its theoretical base by extrapolating the SET which contributes to literature in relation to self-initiated academic expatriates in the Malaysian context. Previously, a review of literature has revealed that organizational trust have been instrumental in enhancing employee intention to remain especially among those who are ordered and financed by the organization they work with, to foreign post. The proposed research framework further posits that self-initiated academic expatriates are more likely to show intention to remain on their job if they gain sufficient trust of their employer's. We conclude that the research framework proposes that organizational trust is significant and positively related to intention to remain.

\section{References}

Abdel-Rahman, G. M., Sri Ramalu, S. \& Subramaniam, C. (2017). The Impact of Cultural Similarity and Social Network Characteristics on Re-Expatriation Intention among Self-Initiated Academic Expatriates. International Journal of Business and Social Research, 7(9), 01-09.

Al-Ali, J. (2008). Emiratisation: Drawing UAE Nationals into Their Surging Economy. International Journal of Sociology and Social Policy, 28(9/10), 365-379.

Al Ariss, A. \& Crowley-Henry, M. (2013). Self-initiated Expatriation and Migration in the Management Literature: Present Theorizations and Future Research Directions. Career Development International, 18(1). 78-96.

Altbach, P. G. \& Knight, J. (2007). The Internationalization of Higher Education: Motivations and Realities. Journal of Studies in International Education, 11(3-4), 290-305.

Balkan, M. O., Serin, A. E., \& Soran, S. (2014). The Relationship between Trust, Turnover Intentions and Emotions: An application. European Scientific Journal, ESJ, 10(2).

Basit, G. \& Duygulu, S. (2018). Nurses' Organizational Trust and Intention to Continue Working at Hospitals in Turkey. Collegian, 25(2), 163-169. http://doi.org/10.1016/j.colegn.2017.05.003

Blau P. (1964). Exchange and Power in Social Life. Wiley: New York

Brashear, T. G., Manolis, C. \& Brooks, C. M. (2005). The Effects of Control, Trust and Justice on 
INTERNATIONAL JOURNAL OF ACADEMIC RESEARCH IN BUSINESS AND SOCIAL SCIENCES

Vol. 8, No. 9, Sept. 2018, E-ISSN: 2222-6990 @ 2018 HRMARS

Salesperson Turnover. Journal of Business Research, 58(3), 241-249.

Cerdin, J. L. \& Selmer, J. (2014). Who is a Self-initiated Expatriate? Towards Conceptual Clarity of a Common Notion. The International Journal of Human Resource Management, 25(9), 1281-1301.

Chemers, M. M., Hu, L.-T. \& Garcia, B. F. (2001). Academic Self-Efficacy and First-Year College Student Performance and Adjustment. Journal of Educational Psychology Pascarella \& Terenzini Bandura \& Jourden, 93(1), 55-64. http://doi.org/10.1037//0022-0663.93.1.55

Colquitt, J. A., Scott, B. A., \& LePine, J. A. (2007). Trust, Trustworthiness and Trust Propensity: A MetaAnalytic Test of Their Unique Relationships with Risk Taking and Job Performance. Journal of Applied Psychology, 92(4), 909.

Costigan, R. D., Insinga, R. C., Berman, J. J., Kranas, G. \& Kureshov, V. A. (2012). A Four-Country Study of the Relationship of Affect-Based Trust to Turnover Intention. Journal of Applied Social Psychology, 42(5), 1123-1142.

Cummings, L. L. \& Bromiley, P. (1996). The Organizational Trust Inventory (OTI). Trust in Organizations: Frontiers of Theory and Research, 302(330), 39-52.

Dalessio, A., Silverman, W. H. \& Schuck, J. R. (1986). Paths to Turnover: A Re-analysis and Review of Existing Data on the Mobley, Horner, and Hollingsworth Turnover Model. Human Relations, 39(3), 245-263.

DeConinck, J. B. (2011). The Effects of Ethical Climate on Organizational Identification, Supervisory Trust and Turnover among Salespeople. Journal of Business Research, 64(6), 617-624.

Dirks, K. T. \& Ferrin, D. L. (2002). Trust in Leadership: Meta-analytic Findings and Implications for Research and Practice. Journal of Applied Psychology, 87(4), 611.

Doherty, N., Richardson, J. \& Thorn, K. (2013). Self-initiated Expatriation and Self-initiated Expatriates. Career Development International, 18(1), 97-112. http://doi.org/10.1108/13620431311305971

Ertürk, A. (2014). Influences of HR Practices, Social Exchange and Trust on Turnover Intentions of Public IT Professionals. Public Personnel Management, 43(1), 140-175.

Ferres, N., Connell, J. \& Travaglione, A. (2005). The Effect of Future Redeployment on Organizational Trust. Strategic Change, 14(2), 77-91. http://doi.org/10.1002/jsc.713

Gillespie, N., Dietz, G. \& Lockey, S. (2014). Organizational Reintegration and Trust Repair After an Integrity Violation: A Case Study. Business Ethics Quarterly, 24(3), 371-410. http://doi.org/10.5840/beq2014437

Goodwin, R. E., Groth, M., \& Frenkel, S. J. (2011). Relationships between Emotional Labor, Job Performance and Turnover. Journal of Vocational Behavior, 79(2), 538-548.

Govaerts, N., Kyndt, E., Dochy, F. \& Baert, H. (2011). Influence of learning and working climate on the retention of talented employees. Journal of Workplace Learning, 23(1), 35-55.

Harhara, A. S., Singh, S. K. \& Hussain, M. (2015). Correlates of employee turnover intentions in oil and gas industry in the UAE. International journal of organizational analysis, 23(3), 493-504.

Harun, S., Asiah, S., Shahid, M. \& Othman, A. K. (2016). The Influence of HRM Practices Towards PHEls Non-Academic Staff Intention to Stay: A Conceptual Model. J. Appl. Environ. Biol. Sci, 6(5S), 8289.

Harzing, A. W. \& Christensen, C. (2004). Expatriate failure: time to abandon the concept? Career Development International, 9(7), 616-626. 
INTERNATIONAL JOURNAL OF ACADEMIC RESEARCH IN BUSINESS AND SOCIAL SCIENCES

Vol. 8, No. 9, Sept. 2018, E-ISSN: 2222-6990 @ 2018 HRMARS

Hassan, M., Toylan, N. V., Semerciöz, F. \& Aksel, I. (2012). Interpersonal trust and its role in organizations. International Business Research, 5(8), 33.

Ibrahim, M. \& AI Falasi, S. (2014). Employee loyalty and engagement in UAE public sector. Employee Relations, 36(5), 562-582.

Isakovic, A. A. \& Forseth Whitman, M. (2013). Self-initiated expatriate adjustment in the United Arab Emirates: a study of academics. Journal of Global Mobility: The Home of Expatriate Management Research, 1(2), 161-186. http://doi.org/10.1108/JGM-09-2012-0011

Jung, H. S. \& Yoon, H. H. (2015). Understanding pay satisfaction: The impacts of pay satisfaction on employees' job engagement and withdrawal in deluxe hotel. International Journal of Hospitality Management, 48, 22-26.

Kashyap, V. \& Rangnekar, S. (2016). Servant leadership, employer brand perception, trust in leaders and turnover intentions: a sequential mediation model. Review of Managerial Science, 10(3), 437-461.

Khoele, A. \& Daya, P. (2014). Investigating the turnover of middle and senior managers in the pharmaceutical industry in South Africa. SA Journal of Human Resource Management, 12(1), 110.

Kyndt, E., Govaerts, N., Dochy, F. \& Baert, H. (2011). The learning intention of low-qualified employees: A key for participation in lifelong learning and continuous training. Vocations and Learning, 4(3), 211.

Leung, M. Y., Liang, Q. \& Chan, I. Y. (2016). Development of a stressors-stress-performance-outcome model for expatriate construction professionals. Journal of Construction Engineering and Management, 143(5), 04016121.

Lewis, L. S., \& Altbach, P. G. (1996). Faculty versus administration: A universal problem. Higher Education Policy, 9(3), 255-258.

Li, J. J., Kim, W. G., \& Zhao, X. R. (2017). Multilevel Model of Management Support and Casino Employee Turnover Intention. Tourism Management, 59, 193-204. http://doi.org/10.1016/j.tourman.2016.08.006

Mayer, R.C., Davis, J.H. \& Schoorman, D.F. (1995). An Integrative Model of Organizational Trust Author(s): Roger C. Mayer, James H. Davis and F. Davis Schoorman Source: The Academy of Management Review, 20(3), 709-734.

Mayer, R. C., \& Davis, J. H. (1999). The Effect of the Performance Appraisal System on Trust for Management: A field Quasi-experiment. Journal of applied psychology, 84(1), 123.

McKnight, D. H., Phillips, B. \& Hardgrave, B. C. (2009). Which Reduces IT Turnover Intention the Most: Workplace Characteristics or Job Characteristics? Information \& Management, 46(3), 167-174.

Morgan, D. \& Zeffane, R. (2003). Employee Involvement, Organizational Change and Trust in Management. International Journal of Human Resource Management, 14(1), 55-75.

Mulki, J. P., Jaramillo, J. F. \& Locander, W. B. (2008). Effect of Ethical Climate on Turnover Intention: Linking Attitudinal-and Stress Theory. Journal of Business Ethics, 78(4), 559-574.

Mustapha, N., Ahmad, A., Uli, J., \& Idris, K. (2010). Mediating Effects of Work-Family Factors in the Relationship between Organizational Characteristics and Intention to Stay. European Journal of Social Sciences, 16(1), 117-136.

Ozturk, A. B., Hancer, M. \& Wang, Y. C. (2014). Interpersonal Trust, Organizational Culture, and 
INTERNATIONAL JOURNAL OF ACADEMIC RESEARCH IN BUSINESS AND SOCIAL SCIENCES

Vol. 8, No. 9, Sept. 2018, E-ISSN: 2222-6990 @ 2018 HRMARS

Turnover Intention in Hotels: A Cross-Level Perspective. Tourism Analysis, 19(2), 139-150.

Park, T. Y. \& Shaw, J. D. (2013). Turnover Rates and Organizational Performance: A MetaAnalysis. Journal of Applied Psychology, 98(2), 268.

Robinson, S. L. (1996). Trust and Breach of the Psychological Contract. Administrative Science Quarterly, 574-599.

Romanowski, M. H. \& Nasser, R. (2015). Identity Issues: Expatriate Professors Teaching and Researching in Qatar. Higher Education, 69(4), 653-671.

Schoepp, K., \& Forstenlechner, I. (2012). Self-initiated Expatriate Faculty in the UAE: Balancing the Profession and Financial Rewards. International Journal of Business and Globalisation, 8(4), 454470.

Schoorman, F. D., Mayer, R. C., \& Davis, J. H. (2007). An Integrative Model of Organizational Trust: Past, present, and future. Academy of Management Reviews, 32(2), 344-354.

Schwepker Jr, C. H. (2001). Ethical climate's relationship to job satisfaction, organizational commitment, and turnover intention in the salesforce. Journal of business research, 54(1), 3952.

Selmer, J. \& Lauring, J. (2011). Acquired demographics and reasons to relocate among self-initiated expatriates. The International Journal of Human Resource Management, 22(10), 2055-2070.

Shahnawaz, M. G. \& Goswami, K. (2011). Effect of psychological contract violation on organizational commitment, trust and turnover intention in private and public sector Indian organizations. Vision, 15(3), 209-217.

Sandhu, M. S., Jain, K. K. \& Ahmad, I. U. K. (2011). Knowledge sharing among public sector employees: evidence from Malaysia. International Journal of Public Sector Management, 24(3), 206-226.

Soomro, B. A., Halepoto, A. H. and Memon, M.S. (2015). Role of Trust and Organizational Commitment on Employee Turnover Study of Non-Banking Financial Institutions of Sukkur Region. International Journal of Management Sciences and Business Research. 4(6), 8-13.

Srivastava, D. K. \& Panday, M. (2012). Dimensions of Indian expatriate adjustment in the USA: An exploratory study. Competitiveness Review, 22(4), 320-328. http://doi.org/10.1108/10595421211247150

Sri Ramalu, S. (2010). Relationship between Cultural Intelligence, Personality, Cross-cultural Adjustment and Job Performance (Published Doctoral Thesis), University Putra Malaysia, Malaysia.

Sri Ramalu, S., Che Rose, R., Uli, J. \& Kumar, N. (2012). Cultural Intelligence and expatriate performance in global assignment: The mediating role of adjustment. International Journal of Business and Society, 13(1), 19-32.

Suliman, A. \& Al Harethi, B. (2013). Perceived work climate and employee performance in public security organizations in the UAE. Transforming Government: People, Process and Policy, 7(3), 410-424.

Suliman, A. \& Al Kathairi, M. (2012). Organizational justice, commitment and performance in developing countries: The case of the UAE. Employee Relations, 35(1), 98-115.

Thirapatsakun, T., Kuntonbutr, C. \& Mechinda, P. (2014). The relationships among job demands, work engagement, and turnover intentions in the multiple groups of different levels of perceived organizational supports. Universal Journal of Management, 2(7), 272-285. 
INTERNATIONAL JOURNAL OF ACADEMIC RESEARCH IN BUSINESS AND SOCIAL SCIENCES

Vol. 8, No. 9, Sept. 2018, E-ISSN: 2222-6990 @ 2018 HRMARS

Tietze, S. \& Dick, P. (2009). Hegemonic practices and knowledge production in the management academy: An English language perspective. Scandinavian Journal of Management, 25(1), 119123.

Tlaiss, H. A. \& Elamin, A. M. (2015). Exploring organizational trust and organizational justice among junior and middle managers in Saudi Arabia: trust in immediate supervisor as a mediator. Journal of Management Development, 34(9), 1042-1060.

Top, M., Akdere, M. \& Tarcan, M. (2015). Examining transformational leadership, job satisfaction, organizational commitment and organizational trust in Turkish hospitals: public servants versus private sector employees. The International Journal of Human Resource Management, 26(9), 1259-1282.

Tourangeau, A., Saari, M., Patterson, E., Ferron, E. M., Thomson, H., Widger, K. \& MacMillan, K. (2014). Work, work environments and other factors influencing nurse faculty intention to remain employed: A cross-sectional study. Nurse Education Today, 34(6), 940-947. http://doi.org/10.1016/j.nedt.2013.10.010

Trembath, J. L. (2016). The professional lives of expatriate academics: construct clarity and implications for expatriate management in higher education. Journal of Global Mobility, 4(2), 112-130.

Womack, A., Leuty, M. E., Bullock-Yowell, E., \& Mandracchia, J. T. (2018). Understanding Commitment: Relations Between Major Commitment, Satisfaction, Involvement, Fit, University Commitment, and Intention to Quit. Journal of Career Development, 45(2), 166-182. http://doi.org/10.1177/0894845316676904

Yuan, L., Yu, Y., Li, J. \& Ning, L. (2014). Occupational commitment, industrial relations and turnover intention: Empirical evidence from China. Chinese Management Studies, 8(1), 66-84.

Zeffane, R. \& Melhem, S. J. B. (2017). Trust, job satisfaction, perceived organizational performance and turnover intention. Employee Relations, 39(7), 1148-1167. http://doi.org/10.1108/ER-062017-0135 